
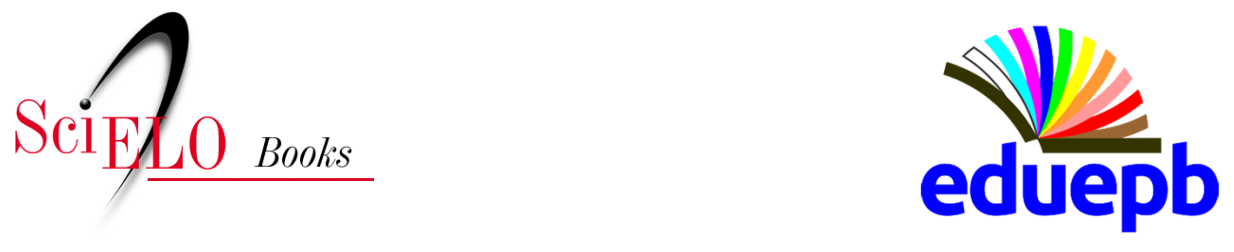

\title{
Aspectos da Teologia Natural na Química de William Prout
}

\author{
José Otavio Baldinato \\ Paulo Alves Porto
}

\section{SciELO Books / SciELO Livros / SciELO Libros}

BALDINATO, J. O., and PORTO, P. A. Aspectos da Teologia Natural na Química de William Prout. In: SILVA, A. P. B., and MOURA, B. A., eds. Objetivos humanísticos, conteúdos científicos: contribuições da história e da filosofia da Ciência para o ensino de Ciências [online]. Campina Grande: EDUEPB, 2019, pp. 131-177. ISBN: 978-8578795-79-5. http://doi.org/10.7476/9786586221664.0005.

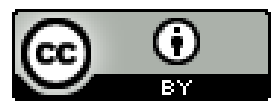

All the contents of this work, except where otherwise noted, is licensed under a Creative Commons Attribution 4.0 International license.

Todo o conteúdo deste trabalho, exceto quando houver ressalva, é publicado sob a licença Creative Commons Atribição 4.0.

Todo el contenido de esta obra, excepto donde se indique lo contrario, está bajo licencia de la licencia Creative Commons Reconocimento 4.0. 


\title{
ASPECTOS DA TEOLOGIA NATURAL NA QUÍMICA DE WILLIAM PROUT
}

\author{
José Otavio Baldinato \\ Instituto Federal de Educação, Ciência e Tecnologia de São Paulo (IFSP) \\ baldinato@ifsp.edu.br
}

\author{
Paulo Alves Porto \\ Universidade de São Paulo (USP) \\ palporto@iq.usp.br
}

\section{Introdução}

Tlustrar como a prática científica interage com fatores sociais, econômicos, políticos, culturais e religiosos é um dos benefíL cios que a história da ciência pode trazer ao ensino de ciências (OLIVEIRA; SILVA, 2011; PORTO, 2010; SEQUEIRA; LEITE, 1988). Apesar disso, são ainda pouco numerosos os trabalhos que aprofundam detalhes dessa última fonte de influências, a religiosidade, sobre o trabalho de cientistas em contextos específicos (LEAL; FORATO; BARCELLOS, 2016).

Neste trabalho, apresentamos a obra do médico e filósofo inglês William Prout (1785-1850) intitulada Chemistry, Meteorology and the Function of Digestion considered with reference to Natural Theology (Quimica, Meteorologia e a função da Digestão consideradas com referência à Teologia Natural)(1834) como exemplo das relações entre o discurso da química e questões religiosas na Inglaterra do início do século XIX. 
A origem do livro remonta a uma herança, no valor de oito mil libras esterlinas, legada ao Presidente da Royal Society $(R S)$ por ocasião da morte de Francis Henry Egerton (1756-1829), conde de Bridgewater. De acordo com o testamento, que foi bastante comentado nas notas obituárias dedicadas a Egerton, o presidente da $R S$ assumiria a incumbência de repassar a referida soma ao autor ou aos autores por ele designados para a composição de trabalhos "Sobre o Poder, Sabedoria e Bondade de Deus manifestos na Criação" (ANÔNIMO, 1829, p.560). Tais obras deveriam ser ilustradas pela maior gama possível de argumentos, e algumas preferências do conde registradas em seu testamento incluíam: a variedade das criaturas pertencentes aos reinos animal, vegetal e mineral; a construção da mão humanae a conversão da matéria - da condição não viva para a viva - pelos efeitos da digestão.

O então presidente da $R S$ era Davies Gilberte os registros da época contam que ele se aconselhou com representantes da Igreja e com os próprios testamenteiros do conde antes de se decidir pela repartição do valor entre vários autores (GILBERT, 1831).

$\mathrm{O}$ processo de escolha envolveu uma negociação difícil e cheia de controvérsias. Os requisitos para os potenciais autores envolviam: 1) reconhecimento da comunidade científica, sendo candidatos, preferencialmente, os membros da $R S ; 2$ ) habilidade literária para escrever a um público educado mas não composto por especialistas; e 3) caráter devoto e ortodoxo em seu posicionamento religioso, assegurando que não escreveriam apenas em função do ganho financeiro envolvido (BROCK, 1966, p.173). Ao final, foram escolhidos sete membros da $R S$ e um teólogo, ficando cada um deles responsável pela produção de um dos volumes da série que seria conhecida como The Bridgewater Treatises. O Quadro 1 apresenta os títulos e autores de cada volume. Todos os textos são hoje de domínio público e se encontram disponíveis em bases digitais de pesquisa. 
Quadro 1 - Relação dos títulos, autores e datas de publicação dos BridgewaterTreatises.

\begin{tabular}{|l|c|c|}
\hline Título do Tratado & Autor & Ano \\
\hline $\begin{array}{l}\text { On the Power, Wisdom and Goodness of } \\
\text { God as Manifested in the Adaptation of } \\
\text { External Nature to the Moral and Intellectual } \\
\text { Constitution of Man }\end{array}$ & $\begin{array}{c}\text { Thomas Chalmers } \\
\text { Professor de Teologia na } \\
\text { Universidade de Edimburgo }\end{array}$ & 1833 \\
\hline $\begin{array}{l}\text { On the Adaptation of the External Nature to } \\
\text { the Physical Condition of Man }\end{array}$ & $\begin{array}{c}\text { John Kidd } \\
\text { Professor de Medicina na } \\
\text { Universidade de Oxford }\end{array}$ & 1833 \\
\hline $\begin{array}{l}\text { Astronomy and General Physics considered with } \\
\text { reference to Natural Theology }\end{array}$ & $\begin{array}{c}\text { William Whewell } \\
\text { Membro do Trinity College, } \\
\text { Cambridge }\end{array}$ & 1833 \\
\hline $\begin{array}{l}\text { The Hand: it's Mechanism and Vital } \\
\text { Endowments as evincing Design }\end{array}$ & $\begin{array}{c}\text { Charles Bell } \\
\text { Médico, Professor de } \\
\text { Anatomia e Cirurgia }\end{array}$ & 1833 \\
\hline On Animal and Vegetable Physiology & $\begin{array}{c}\text { Peter Mark Roget } \\
\text { Professor de Fisiologia na } \\
\text { Royal Institutione Secretário } \\
\text { da RS }\end{array}$ & 1834 \\
\hline $\begin{array}{l}\text { William Buckland } \\
\text { On Geology and Mineralogy }\end{array}$ & 1836 \\
\hline $\begin{array}{l}\text { Onigestion considered with reference to Natural } \\
\text { Theology }\end{array}$ & $\begin{array}{c}\text { Médico, Membro do Royal } \\
\text { College of Physicians }\end{array}$ & 1834 \\
\hline Animals & Universidade de Oxford & \\
\hline Wabits and Instincts of & $\begin{array}{c}\text { William Kirby } \\
\text { Entologista, Clérigo da }\end{array}$ & 1835 \\
\hline
\end{tabular}

Embora caros, os tratados alcançaram grande circulação, registrando vendas da ordem de 60.000 exemplares entre as décadas de 1830 e 1850 . De fato, o preço de cada volume era proibitivo às classes operárias e ia na contramão das publicações baratas que se tornaram amplamente difundidas no segundo quarto do século 
(LIGHTMAN, 2007; TOPHAM, 1992, p.397-402)57. Assim, o alcance da coleção se deu, em grande parte, pela sua presença nas bibliotecas de Associações e Institutos dedicados à disseminação de saberes, tanto da filosofia natural quanto da teologia.

Questionando o uso dos tratados por grupos educacionais do período, como as Escolas Dominicais e os Institutos de Mecânica, Topham (1992) argumenta que o preço era compensado pela profundidade das abordagens. Assim, esses grupos valorizavam os volumes como tratados filosóficos acessíveis, que guardavam o mérito de serem assinados por autores de reconhecida competência em suas áreas, mostrando-se atualizados, mas sem se aprofundarem em questões muito técnicas ou específicas. Na leitura de Topham (1992, p.403-404), outra questão determinante foi o fato dos tratados serem considerados "seguros" no sentido de preservarem compromissos religiosos, políticos e sociais dessas comunidades.

Topham (1998) procedeu um estudo cuidadoso do circuito da comunicação dos Bridgerwater Treatises, destacando que, apesar do preço, a série teve ampla circulação entre diversos grupos de leitores. Sobre os autores, afirma-se que eles não receberam uma encomenda suficientemente detalhada a ponto de tornar homogêneo o padrão das abordagens. Ainda assim, alguns aspectos comuns são perceptíveis, como o fato de nenhum deles ter

57 Os volumes de Whewell e Kidd eram os mais baratos da série, tendo suas primeiras edições vendidas ao preço final de 9 shillings e 6 pence. Já o tratado de geologia de Buckland, sob a justificativa das muitas e detalhadas ilustrações, custava 1 libra e 15 shillings. O texto de Prout era vendido por 15 shillings. No sistema monetário inglês da época, cada libra era dividida em vinte shillings e cada shilling em doze pence. Com o avanço das técnicas de impressão no segundo quarto do século, muitos editores investiram na ampliação do seu mercado pela redução do preço final das publicações. Enquanto livros seriados ao preço de 6 shillings eram acessíveis "aos leitores da classe média e a alguns dos artesãos mais prósperos", revistas semanais de 6 pence se tornaram bastante populares (LIGHTMAN, 2007, p.19). 
dedicado seu tratado a uma exposição estrita da filosofia atrelada ao argumento do design na Natureza. Em vez disso, os textos se ocupam, prioritariamente, de apresentar os fundamentos de cada ramo da filosofia natural, valorizando ilustrações das instâncias em que o design se mostraria de forma mais evidente. As propostas também se aproximam na medida em que os autores as dirigem, claramente, para um público de não especialistas. Topham observa, ainda, que os autores planejaram seus textos pensando em alcançar diferentes níveis de leitura, apresentando as bases de suas áreas de investigação, mas também sugerindo rumos, além de novos dados e interpretações, aproveitando-se dos volumes para dar contribuições originais aos seus campos do conhecimento.

[...] as ambiguidades inerentes aos Bridgewater Treatises são particularmente profundas: estas eram obras cujo gênero não poderia ser facilmente definido. Elas foram amplamente resenhadas tanto em periódicos religiosos quanto nos especializados, e foram lidas tanto por especialistas científicos quanto por leigos. No entanto, são precisamente essas ambiguidades que tornam os Bridgewater Treatises particularmente úteis para explorar o lugar da ciência na cultura mais ampla(TOPHAM, 1998, p.239).

A proposta inicial do presidente da $R S$ para o tratado envolvendo a química tinha foco nos agentes imponderáveis e os possíveis autores seriam William Prout ou David Brewster (1781-1868). Historiadores que se debruçaram sobre os registros desse processo especulam que a escolha por Prout e a mudança no foco da obra se deveram às relações pessoais do autor, que era próximo de Gilbert e também de Roget - secretário da $R S$ e autor do Bridgewater Treatise sobre fisiologia animal e vegetal -, além de seu reconhecido interesse pelo tema da digestão, 
que fora explicitamente mencionado no testamento do conde de Bridgewater (BROCK, 1966, p.168-169; ROBSON, 1990, p.73). Para o estudo que apresentamos na sequência, foi considerada a primeira edição do tratado de Prout(1834).

\section{William Prout e o oitavo Bridgewater Treatises}

Prout participa da historiografia da química em função da hipótese que leva seu nome e que remete a uma suposta constituição comum de todos os elementos químicos, cujos pesos atômicos relativos seriam múltiplos do peso do hidrogênio (GLASSTONE, 1947). No entanto, sua atividade principal era a prática da medicina e, nesta área, tanto seus interesses quanto a trajetória que desenvolveu aproximam sua história às de outros médicos químicos do período, como foi o caso de Alexandre Marcet (COLEY, $1968)^{58}$.

Prout veio de uma família humilde que vivia no condado de Gloucestershire, no interior da Inglaterra. Teve acesso à educação elementar até os treze anos e, no início da vida adulta, frequentou seminários ligados a duas Instituições religiosasque lhe proporcionaram a formação mínima necessária para o ingresso em cursos universitários, incluindo rudimentos de grego e latim (BROCK, 1965, p.102).

58 Alexandre Marcet (1770-1822) foi um médico e químico influente nas primeiras décadas do século XIX. Nascido em Genebra e radicado em Londres, manteve amizade com homens de ciência como os químicos H. Davy (17781829), W.Wollaston (1766-1828) e J.J. Berzelius (1779-1848), o botânico A.P. de Candolle (1778-1841) e o economista político T. Malthus (1766-1834). Na historiografia da ciência, Alexandre é mais conhecido em função do trabalho de sua esposa, Jane Marcet (1769-1858), que publicou obras de divulgação prestigiadas em campos como a química, fisiologia vegetal, linguagens e política econômica (BAHAR, 2001; DREIFUSS; SIGRIST, 2012; LINDEE, 1991; ROSENFELD, 2001). 
Pouco mais de uma década depois de Alexandre Marcet, Prout também frequentou a Universidade de Edimburgo e, em seguida, se estabeleceu em Londres como médico e professor. Os dois chegaram a trabalhar juntos no Guy's Hospital por um curto período na década de 1810, e há registros da Instituição enaltecendo o trabalho de ambos que, junto a Wollaston e John Yelloly (1774-1842), avançaram o conhecimento médico com pesquisas sobre cálculos e depósitos urinários, aprimorando diagnósticos e tratamentos (BIRD, 1842).

A partir de 1813, Prout passou a atender os pacientes em seu próprio endereço, mas se manteve ativo como membro de sociedades filosóficas. Entre elas estavam a Medico-Chirurgical Society, o Royal College of Physicians e a Royal Society, que o elegeu, em 1819, mediante indicação escrita e assinada por Marcet, e co-assinada por sete outros membros da Sociedade (ANÔNIMO, 1850, p.16).

Os registros biográficos enfatizam que Prout era um madrugador, e que conduzia suas pesquisas experimentais pela manhã, antes de começar o atendimento dos seus pacientes (ANÔNIMO, 1850, p.17; BROCK, 1965, p.124). Além das análises urinárias, seu interesse por processos fisiológicos como a digestão e a respiração se desdobrou em pesquisas que incluíram: a quantificação do ácido carbônico emitido na respiração; a formação dos componentes do sangue a partir da digestão dos alimentos; a identificação do ácido muriático como responsável pela ação do suco gástrico e a análise da composição de diversos compostos organizados, como açúcares, ácidos vegetais e a ureia (PROUT, 1827). Prout também se dedicou a estudos meteorológicos, realizando medições da gravidade específica do ar e investindo significativamente na construção de equipamentos, como um barômetro que serviu de modelo ao que seria instalado na Royal Society sob sua supervisão. Para um relato detalhado dessas atividades, remetemos à biografia compilada por Brock (1965). 
Em relação à sua hipótese unitária, os resultados que formalizam essa contribuição foram originalmente publicados sob anonimato, em dois artigos do periódico Annals of Philosophy, editado por Thomas Thomson (1773-1852). As conclusões de Prout se fundamentavam na comparação entre os pesos atômicos relativos determinados para vários corpos elementares e suas respectivas gravidades específicas no estado gasoso. Prout tinha suas análises químicas orientadas pela doutrina das combinações volumétricas de Gay-Lussac e, no primeiro artigo, chegou a afirmar que, caso suas conclusões fossem verificadas por outros autores, lançar-se-ia "uma nova e interessante luz sobre toda a ciência da química” (PROUT, 1815, p.321).

$\mathrm{O}$ artigo se iniciava sugerindo que o oxigênio e o azoto (nitrogênio), no ar atmosférico, deveriam ser entendidos como constituintes de um composto químico, pois esta seria a única maneira de justificar sua distribuição em proporção fixa em todos os lugares ao redor do globo terrestre. Assumindo a gravidade específica do ar atmosférico como um padrão de valor unitário, Prout propôs um método para a determinação da gravidade específica do gás hidrogênio que não envolvia a sua medição direta, mas um cálculo derivado da sua presença em compostos como a amônia, por exemplo, em que este gás se combina com azoto na proporção de 3:1 em volume. Tomando emprestadas as medidas obtidas por Davy, Biot e outros contemporâneos para vários compostos, Prout determinou o valor de 0,0694 para a gravidade específica do gás hidrogênio, e notou que o mesmo método, aplicado a outras substâncias elementares, gerava resultados que eram (com razoáveis aproximações) múltiplos inteiros desse valor (PROUT, 1815) ${ }^{59}$.

59 Os valores apresentados para as gravidades específicas, em relação ao do gás hidrogênio, foram: carbono, 12; nitrogênio, 14; fósforo, 14; oxigênio, 16; enxofre, 16; cálcio, 20; sódio, 24; ferro, 28; zinco, 32; cloro, 36; potássio, 40; bário, 70 e iodo, 124. Prout (1815) chamou a atenção para o fato de todos os valores 
Esses cálculos, junto a uma série de tabelas que organizavam seus resultados, foram publicados na edição de novembro de 1815 do periódico de Thomson. Já em fevereiro do ano seguinte, uma errata corrigiria uma das tabelas e acrescentaria ao artigo a conclusão que ficou conhecida como hipótese de Prout. Chamando a atenção para os valores apresentados, Prout comparou o hidrogênio com a hyle $e^{60}$ dos filósofos gregos, sugerindo que todos os outros elementos poderiam ser formados por diferentes porções combinadas desta matéria primeira, a proto-hylé, ou hidrogênio (PROUT, 1816, p.113). A autoria da hipótese foi revelada ainda no ano de 1816, pelo editor do periódico (THOMSON, 1816, p.343).

Ao leitor com formação em química, é interessante ressaltar como os argumentos usados por Prout nesses artigos pressupunham teorias que hoje nos são familiares, mas que à época se encontravam longe de serem disseminadas entre os filósofos químicos. Entre elas destacamos a ideia de que volumes iguais de quaisquer gases, em condições definidas, encerram em si quantidades equivalentes de partículas, e também a aceitação de que substâncias simples como os gases hidrogênio e nitrogênio poderiam ser formadas por mais de um átomo, constituindo o que hoje chamamos de moléculas. A repercussão da hipótese é detalhada por Glasstone (1947), que acompanhou as opiniões de vários químicos sobre o tema ao longo do século XIX e início do século XX. Em particular, cabe ainda destacar que o argumento de Prout influenciou os trabalhos de muitos autores que se dedicaram às tentativas de classificação dos elementos químicos, incluindo os

serem múltiplos de dois, sugerindo uma composição comum a todos os corpos elementares.

60 Hylé é o termo grego para "matéria”. Em Aristóteles, a proto-hylé é apresentada como um tipo de matéria primordial, da qual seriam constituídos os elementos fogo, terra, água e ar (AINSWORTH, 2016). 
sistemas periódicos de J. Lothar Meyer (1830-1895) e de Dmitri Mendeleev (1834-1907) (GORDIN, 2012) ${ }^{61}$.

De acordo com Brock (1965, p.102), as pesquisas perderam espaço na rotina de Prout na década de 1830, e após a publicação do seu Bridgewwater Treatise ele teria passado a se dedicar essencialmente à prática da medicina e à revisão dos seus livros.

Os registros encontrados fornecem poucas informações sobre a vida pessoal de Prout e quase nada sobre as suas inclinações religiosas. Além de ter frequentado seminários sob a tutela de homens da igreja antes de ingressar na faculdade de medicina, sabe-se que ele se casou com Agnes Adam (1793-1863) em 1814, e que um dos seus sete filhos, Thomas Jones Prout (1823-1909), se tornou clérigo e professor de culturas clássicas na Christ Church, pertencente à Universidade de Oxford. Assim, é difícil avaliar o quanto Prout cumpria com o terceiro dos requisitos colocados aos autores dos Bridgewater Treatises, isto é, o de manter caráter devoto e ortodoxo, que não lançasse dúvidas sobre suas intenções ao publicar um livro com enfoque teológico. Como veremos na sequência, ao detalhar o conteúdo do texto, são perceptíveis algumas inconsistências no argumento teológico apresentado por Prout, mas é inegável que uma visão vitalista se coloca como pano de fundo em toda a obra.

\section{A química sob a ótica da teologia natural}

O Bridgewater Treatise de Prout foi dividido em três partes, abordando a química, a meteorologia e a digestão em tomos separados, com cerca de 180 páginas cada um. O volume é dedicado a

61 Na década de 1870, Mendeleev tomava a hipótese de Prout como uma especulação refutada pela experiência ligada à quantificação precisa dos pesos atômicos. Ainda assim, no livro didático em que sistematizou sua tabela periódica, o autor se refere à hipótese como algo "muitíssimo importante, e que merece plenamente a atenção que tem sido dedicada a ela" (MENDELEEV, 1891, p.406). 
Davies Gilbert, que presidiu a $R S$ entre 1827 e 1830 e que encaminhou a escolha dos autores para a série de tratados.

Prout sintetizou na introdução o que entendia como o argumento principal da teologia natural, a saber, "que o design, ou a adaptação de meios para um fim, existe na Natureza" (PROUT, 1834, p. XXV). Tal argumento é apresentado na forma de um exemplo simples, que observa providência no fato dos animais serem perfeitamente adaptados às condições do ambiente em que vivem.

Animais que vivem em climas frios foram munidos de uma cobertura de pele. $\mathrm{O}$ homem em tais climas se cobre com esta pele. Em ambos os casos, independente de qual tenha sido o fim ou o objetivo, ninguém pode negar que ao menos o efeito é precisamente o mesmo: o animal e o homem são igualmente protegidos do frio. Mas como o animal não cobriu a si mesmo, mas deve ter sido coberto por um outro; segue-se que, quem quer que tenha vestido o animal deve saber aquilo que o homem sabe, e deve ter raciocinado como o homem [...].

O homem que se cobre com pele para se proteger do frio executa um ato direcionado a um certo fim; um ato de design. Assim, aquele que, direta ou indiretamente, fez com que o animal fosse revestido de pele para se proteger do frio deve ter, da mesma forma, executado um ato de design.

Mas, dadas as circunstâncias, deve-se admitir que aquele que vestiu o animal tenha sido, também, o Criador do animal; e por extensão do argumento; o Criador do próprio homem - do universo. Além disso, o raciocínio que o Criador demonstrou ao vestir o animal, Ele concedeu espontaneamente ao homem, que 
é, assim, capaz de reconhecer o design do seu Criador(PROUT, 1834, p. XXV-XXVI, itálicos no original).

De acordo com as explicações do autor, o argumento do design abrangeria ao menos três classes de objetos, sendo elas separadas pela capacidade do homem de identificar, pela razão, os meios e os fins envolvidos na obra do Criador.

A primeira classe se daria nas ocasiões em que a razão do homem se mostra capaz de acompanhar plenamente a razão evidenciada por Deus, isto é, quando são claros quais meios foram mobilizados para quais fins. Este é o caso da pele dos animais, que os protege do frio no exemplo inicial do autor, mas também estariam nesta classe vários fenômenos regidos pela noção de quantidade numérica, como os estudados pelo campo da mecânica.

A segunda classe de objetos incluiria os fenômenos dos quais o homem pode perceber apenas os estados inicial e final, sem enxergar uma descrição dos mecanismos ou dos meios pelos quais se alcançam aqueles fins. Segundo esse discurso preliminar de Prout, a esta classe pertenceriam todos os fenômenos estudados pela química.

Já a terceira classe seria aquela na qual tanto os meios de operação quanto os fins almejados pelo Criador escapam à razão do homem, permitindo-se, então, apenas a inferência de um necessário design. Prout cita como exemplos dessa categoria a existência das estrelas fixas, dos cometas e da vida organizada (PROUT, 1834, p. XXVII).

Todas essas considerações sobre o argumento da teologia natural são rapidamente apresentadas na introdução do volume e, a partir desse ponto, o autor frisa que a intenção do tratado seria apenas explicitar várias evidências de design perceptíveis nos objetos da criação, "deduzindo, a partir delas, a existência e os atributos do Criador” (PROUT, 1834, p. XXVIII). 
Essa perspectiva de apresentar uma coleção de exemplos independentes enfatiza o caráter acumulativo do argumento do design. De acordo com William Paley (1802/2006, p.45-46), que foi autor de uma das principais obras de referência sobre teologia natural publicadas no período, a força do argumento não admitiria paralelo com uma corrente, que se quebra pela fraqueza de um único elo, mas com uma corda trançada por muitos fios individuais. Cada exemplo de design encontrado na Natureza corresponderia a um fio e, assim, se algum deles se mostra fraco e sucumbe à crítica, este pode ser abandonado sem comprometer a integridade do argumento.

Paley é referenciado por Prout, em vários momentos, como a principal fonte para o leitor interessado em se apropriar dos fundamentos desse argumento teológico que, em resumo, buscava demonstrar a existência de Deus por meio da investigação filosófica da Natureza, sem recorrer a qualquer forma de revelação. No entanto, é importante ressaltar que a teologia natural encontrada nos Bridgerwater Treatises não é uma simples extensão daquela que fora defendida por Paley no início do século. O discurso teológico dos tratados trazia características próprias e que variavam de autor para autor (TOPHAM, 1993). Prout se apoia em argumentos lançados por Paley, mas não tem a intenção de provar a existência de Deus como resultado da investigação química. Diferente disso, ele parte da premissa de que todo o mundo natural é obra de um Criador infinitamente sábio e benevolentee se propõe apenas a demarcar reflexos aparentes desses atributos ${ }^{62}$. Essa característica

62 Alguns autores propuseram rótulos como "teologias da natureza" (BROOKE, 1974, p.9) ou "discursos de design" (TOPHAM, 2004, p.38) para diferenciar esta linha de argumentação (que assume um compromisso prévio com a existência de Deus, apenas apresentando os fenômenos naturais como reflexos da sua onipotência) daquela que corresponderia propriamente à teologia natural (quando se pretende comprovar a existência de Deus por meio da investigação filosófica, sem recorrer à revelação). O texto de Prout se enquadraria, portanto, 
da série de tratados motivou críticas em algumas das resenhas publicadas na época.

Pelo que vimos dos Bridgewater Treatises, devemos dizer que eles são mais apropriados para confirmar a fé do que para instituí-la. O fato é que Paley deixou o argumento principal da religião natural numa condição pouco menos que perfeita. Se o design prova a existência de Deus, Paley provou a existência de design(ANÔNIMO, 1836, p.386).

O primeiro tomo do livro traz um conjunto inicial de capítulos sobre as leis gerais da Natureza e os agentes primeiros, como a eletricidade, a luz e o calor. $\mathrm{Na}$ sequência, o estudo dos corpos materiais segue a lógica que vai do mais simples ao mais complexo. Prout divide as substâncias elementares em grupos, comentando as propriedades conhecidas de cada elemento, suas fontes naturais, abundância e usos mais comuns. Em seguida, trata das leis de combinação valorizando uma versão adaptada da teoria atômica da Dalton, e finaliza com uma extensa classificação das substâncias compostas, incluindo ácidos, bases e sais.

A leitura completa do tratado revela uma rotina que se repete em vários momentos. Ao encerrar um capítulo contendo muitos argumentos químicos, Prout resume e lista os pontos principais da teoria explicada antes de apresentar sua leitura teológica derivada daquelas ideias. Explicitamente, o autor admite que o argumento de conexão entre a química e a teologia deveria ser a parte mais atrativa do texto, e antecipa que muitos leitores pulariam as partes do tratado dedicadas exclusivamente à química, talvez por já

nesses rótulos. No entanto, optamos por manter o uso da expressão teologia natural por ser este o termo empregado pelo próprio Prout no contexto estudado. 
conhecerem seus princípios, ou mesmo por não apresentarem interesse nesse aprofundamento (PROUT, 1834, p.82-122).

A narrativa se inicia com considerações gerais sobre a posição ocupada pela química enquanto ciência e sobre a sua aplicação ao argumento do design. Nessas observações preliminares, o autor admite dois tipos de conhecimento humano, um do que "deve ser" e outro do que "simplesmente é" (PROUT, 1834, p.2). O primeiro se fundaria na razão, remetendo às questões para as quais o ser humano é capaz de fomentar explicações consideradas livres de dúvidas. As relações de quantidade da química estariam nesta classe. Já o segundo tipo de conhecimento teria contorno mais descritivo do que propriamente explicativo, sendo, portanto, pautado pela experiência e não pela razão. Estariam nessa classe a grande maioria dos saberes típicos da química. Em termos práticos, essa divisão admitia que, em química, pode-se prever quanto será formado de um certo produto novo, mas não qual será a sua cor ou cheiro. As relações de quantidade estariam plenamente sob o domínio da razão, mas o conhecimento sobre as qualidades secundárias dos corpos se daria apenas pela experiência.

Descrevendo os experimentos como situações controladas de observação, nas quais algumas causas e agentes conhecidos são manipulados de modo a tornar perceptíveis seus efeitos, Prout destaca que, nas áreas mais avançadas do conhecimento, obtêm-se informações tão seguras sobre a matéria, sua agregação e movimento, que podem se fundar certezas apoiadas nas relações de quantidade. A incerteza surgiria quando o conhecimento derivado dos objetos é apenas sensível e não quantificável. Esta fragilidade estaria ligada à nossa ignorância sobre o funcionamento dos sentidos humanos.

Prout alega que o ouvir e o ver já haviam sido explicados como dependentes de uma forma de movimento, vibracional ou ondulatório, que entra em contato com o ouvido ou com os olhos - mesmo não se sabendo o efeito fisiológico a partir daí. Já o 
paladar e o olfato são tratados como um mistério, uma vez que dispensavam o intermediário (que vibra) pelo contato direto do corpo produtor da sensação com o órgão que sente. As relações de quantidade não pareciam imediatamente aplicáveis aí, e isso seria um problema inerente à química (PROUT, 1834, p.7-8).

De fato, a química tanto é criatura da efetiva pesquisa experimental, que mesmo as suas verdades mais simples foram raramente antecipadas a priori. Por exemplo, milênios de observação e experiência não mostraram à humanidade que a água é composta de dois princípios gasosos elementares, muito menos as proporções nas quais tais princípios se combinam para formar água. Mais ainda, mesmo que o fato esteja hoje estabelecido sobre as mais claras evidências, somos incapazes de explicar o seu porquê, ou mesmo de entender a natureza da união ou seu resultado (PROUT, 1834, p.8-9).

Em resumo, a química de Prout seria uma ciência fundada sobre a experiência, mas ainda que os mecanismos dos seus objetos de estudo fossem obscuros, sinais de design seriam perceptíveis nos seus resultados. Isso colocava os objetos da química na segunda classe do argumento de design. Prout valoriza essa conclusão ao sugerir que Deus limitaria muito seu poder ao operar sobre a criação por meios mecânicos, dada a simplicidade e até certo grau de obviedade desta via. Sua atuação pareceria muito mais livre e maravilhosa quando se fazia por vias químicas, pois, sendo essas mais misteriosas, despertariam maior admiração (PROUT, 1834, p.11).

Depois dessas considerações iniciais, o texto apresenta uma sequência de capítulos tratando das leis gerais que teriam sido criadas por Deus e pelas quais ele atuaria sobre a criação. Neste 
ponto, Prout apoia toda a narrativa num argumento apresentado por Paley (1802/2006, p.27), de que Deus, ao definir um conjunto fundamental de leis naturais, estabeleceu limites para a sua própria capacidade e operou toda a criação obedecendo a esses limites.

De acordo com Paley, as leis de inércia, comunicação do movimento, reação, refração e reflexão da luz, constituição dos fluidos elásticos, propagação do som, magnetismo, eletricidade e outras ainda desconhecidas, teriam sido estabelecidas antes da criação das espécies vivas (1802/2006). Assim, todas as formas de vida foram criadas em observância a essas leis e tiveram suas funções projetadas para que pudessem ser executadas sem desrespeitar as propriedades daquilo que foi criado primeiro. A complexidade dos mecanismos necessários para que se formasse, por exemplo, o sentido da visão, serviria para nos despertar a admiração pela infinita capacidade do Criador ao lidar com as leis que ele mesmo estabeleceu. Para Paley, se tudo fosse simples e imediato, não se instigaria esse senso de contemplação. Isso não sugere que o Criador não tivesse um plano completo da sua obra desde o início e que foi adaptando cada nova ideia que lhe surgia. A criação das leis e corpos primeiros, como o ar e a água, já previa o seu uso por seres viventes que viriam depois. Prova disso seriam as proporções perfeitas com que Deus preencheu o mundo desses princípios vitais. Prout compartilha dessa visão e descreve algumas leis nos primeiros capítulos do livro, começando pela inércia e pela atração gravitacional.

Ao chegar à abordagem dos fenômenos químicos, o autor relembra que estes nos permitiriam observar com clareza apenas as suas condições inicial e final. Os mecanismos e etapas da mudança química se processariam por meios que o filósofo poderia apenas especular. Ainda assim, Prout julga adequado teorizar sobre as interações que deveriam ocorrer entre os constituintes mínimos da matéria e se alonga nessa explicação. 
Para Prout, não havia dúvidas de que a matéria neste mundo era composta de partículas mínimas que não podiam ser divididas ou alteradas. A possibilidade de compressão mecânica dos corpos seria uma evidência da existência de interstícios entre essas partículas. Ele retira um exemplo de cada reino para ilustrar o quão diminutas podem ser as formas organizadas em minerais, fungos ou "animálculos"(PROUT, 1834, p.24). Daí se deduziriam as pequeníssimas dimensões e a quase infinita quantidade de partículas últimas que deveriam compor esses corpos.

Utilizando-se de uma série de desenhos esquemáticos, o autor tenta explicar a agregação dos corpos sólidos com base em polos atrativos e repulsivos das partículas individuaisque dirigiriam sua interação com as vizinhas. Cada partícula é representada como uma esfera dotada de forças axiais, conforme ilustra a Figura 1. Essas forças são divididas por Prout (1834, p.44) entre “polarização química” e "polarização coesiva”, e correspondem, respectivamente, ao que outros autores da época chamavam de forças de combinação e de coesão (MARCET, 1832; PARKES, 1826). O primeiro tipo de polarização responderia pela atração entre partículas de naturezas diferentes, como hidrogênio e oxigênio formando a água, enquanto o segundo tipo se restringiria à atração de partículas iguais, orientando a agregação de várias partículas de água na formação de um cubo de gelo, por exemplo. Prout afirma que essas forças seriam de natureza análoga às forças elétrica e magnética, adotando a versão da teoria que associava duas naturezas possíveis (positiva e negativa/norte e sul) a cada uma dessas forças. 


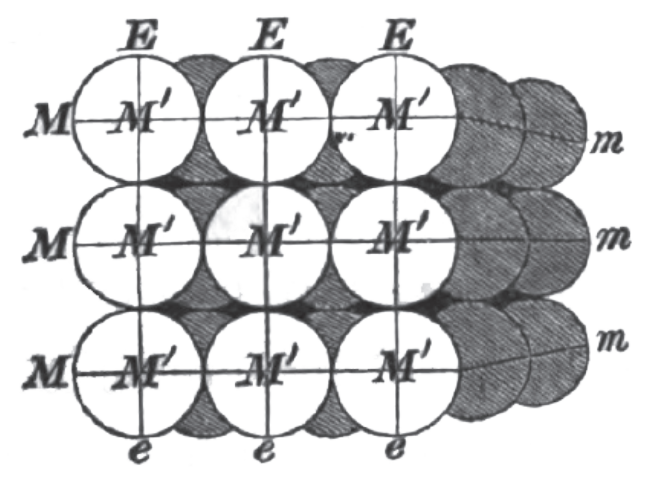

Figura 1. Representação da agregação de partículas num sólido pela atração entre eixos polarizantes $\overline{\mathrm{Ee}}$ (na vertical), $\overline{\mathbf{M m}}$ (na horizontal) e $\overline{\mathbf{M}^{\prime} \mathbf{m}^{\prime}}$ (perpendicular ao plano do papel) (PROUT, 1834, p.32).

Prout questiona qual seria o resultado do equilíbrio dado pela junção das duas naturezas elétricas ou das duas naturezas magnéticas, sugerindo que tais fenômenos dariam origem ao calor. Embora, neste primeiro momento, o autor se recuse a dar como certa essa interpretação, ela é claramente adotada em outras partes do texto.

Ao falar sobre a causa material da sensação de calor, Prout apresenta a teoria do fluido calórico e também a do movimento vibracionalque dispensava este agente imponderável. No entanto, essas duas ideias são rapidamente descartadas pelo autor, que assume uma terceira corrente para interpretar os fenômenos ligados à conversão de corpos sólidos em líquidos ou gases. Segundo ele, o calor e também a luz deveriam ser entendidos como substâncias semelhantes à matéria ponderável em todas as suas características, sendo compostas por moléculas submetidas às mesmas leis que se aplicam à matéria em geral. Essa noção se apoiava na hipótese de que o calor poderia ser um composto formado pela junção das eletricidades positiva e negativa. Por extensão desse raciocínio, a possibilidade de decomposição do calor em seus componentes 
elétricos é usada por Prout para explicar o calor latente envolvido nos processos de fusão, justificando o desaparecimento do calor absorvido por um sólido que passa ao estado líquido sem registrar variação de temperatura.

Nesses processos, Prout sugere que as moléculas de calor se arranjariam como uma atmosfera ao redor das partículas do corpo aquecido (Figura 2A). Tal recobrimento já responderia pela redução da sua atração mútua, permitindo um pequeno afastamento que justificava a expansão volumétrica do material. No entanto, outra porção do calor adicionado sofreria decomposição, ampliando a intensidade dos eixos de polarização elétrica das partículas. Essa alteração do componente elétrico das partículas promoveria a sua rotação em torno do eixo de polarização magnética (Figura 2B), levando a uma nova condição de equilíbrio na qual as partículas vizinhas se manteriam próximas, mas com maior liberdade de movimentação, compondo um corpo fluido, ou líquido.

(A)

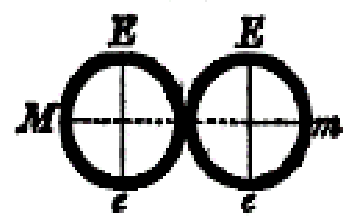

(B)

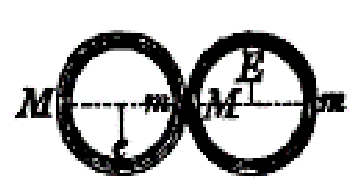

(C)

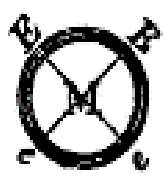

Figura 2. Representação da ação do calor sobre as partículas de um sólido que se converte em líquido (PROUT, 1834, p.55).

Percebe-se, pela interpretação da Figura 2C, que o eixo de polarização $\overline{E e}$ alcançaria uma nova condição de equilíbrio, dando estabilidade ao líquido após um movimento de rotação que coloca em ângulo reto os eixos de partículas vizinhas. Prout amplia esse argumento para afirmar que, na ebulição, a decomposição de grandes quantidades de calor faria com que esses eixos de polarização 
se colocassem em posição paralela, de modo a maximizar as forças auto-repulsivas entre partículas vizinhas, dando origem a um gás. Neste trecho das explicações, Prout enuncia claramente o que viria a ser conhecido posteriormente como hipótese de Avogadro, afirmando que "todos os corpos gasosos, sob a mesma pressão e temperatura, contêm igual número de moléculas auto-repulsivas" (PROUT, 1834, p.62). De acordo com o autor, essa ideia era necessária para que se pudesse explicar a expansão volumétrica comum entre os gases mediante adições controladas de calor. Prout esclarece, numa nota de rodapé, que já adotava essa interpretação muito antes de tomar ciência dos ensaios publicados por Avogadro, Ampère e Dumas sobre o assunto.

$\mathrm{O}$ texto segue detalhando propriedades do calor e seu movimento por irradiação, condução e convecção, sendo este último termo uma proposição original de Prout para se referir ao calor que é conduzido pela movimentação das partículas de um material aquecido, seja líquido ou gás, sempre de baixo para cima (PROUT, 1834, p.65).

Passando do calor à luz, Prout descreve as propriedades conhecidas como reflexão, refração, polarização e decomposição no espectro de cores. O último capítulo deste bloco lista as fontes comuns de luz e calor, incluindo o sol, a eletricidade, a ação mecânica, mudanças de condição física ou química dos corpos, além do que o autor chama de "ação orgânica", referindo-se ao calor produzido por processos químicos internos dos animais (PROUT, 1834, p.80).

No resumo que precede seu argumento teológico, Prout lembra que este primeiro bloco de capítulos tratava dos agentes e das leis gerais da Natureza como princípios de ação aos quais o Criador teria se limitado em todos os atos posteriores da sua obra. Em particular, as leis de propagação da luz e do calor seriam fundamentais na configuração dos componentes do clima na Terra, configurando um prólogo necessário ao tomo do livro sobre a 
meteorologia (PROUT, 1834, p.82). Sobre a matéria, Prout destaca em seu resumo que ela é constituída por moléculas esferoidais, individualmente submetidas a forças polarizantes análogas às forças elétrica e magnética. Essas forças atuariam tanto sobre a matéria ponderável quanto a imponderável, dirigindo a interação das partículas de modo a justificar sua agregação e os diferentes estados físicos dos materiais. A partir desses argumentos, Prout deduz como livre de controvérsia que: 1) a matéria não mantém desde sempre a sua organização atual; 2) ela não chegaria a existir na condição atual por acaso; e 3) sua configuração atual reflete o trabalho de um Ser inteligente, que atua de modo intencional (PROUT, 1834, p.86).

Como justificativas para suas conclusões, Prout argumenta que a composição molecular da matéria traz como característica essencial a capacidade de movimento, entendido aqui com sentido de mudança ou transformação. Essa capacidade sensível eliminava a possibilidade de que a matéria fosse eterna, pois, nas palavras do autor, "a existência eterna (passiva) necessariamente implica a incapacidade de mudança” (PROUT, 1834, p.87).

Prout toma como absurda a possibilidade de que o acaso pudesse produzir qualquer corpo material cuja constituição se dê pela junção de inúmeras partículas moleculares idênticas entre si, pois o acaso levaria a resultados aleatórios e não repetitivos.

Não é fato que tomamos como objeto de admiração quando duas ou três coisas, por acaso, se mostram semelhantes, como dois ou três rostos humanos, por exemplo? Não deveríamos tomar por louco alguém que atribui ao acaso a uniformidade das manobras de um regimento de soldados? (PROUT, 1834, p.88).

Pela linha de raciocínio do autor, infere-se inteligência pelo ajuste dos processos aos fins a que se destinam. Uma composição 
molecular submetida à polarização química (de combinação) e coesiva (de agregação) seria, dentre todas as possíveis, a forma mais adequada para permitir a ocorrência dos fenômenos naturais com os quais estamos habituados. Tal percepção leva o autor a deduzir, em tom seguro, a necessidade de um ser onisciente e anterior ao tempoque pudesse criar a matéria e aplicar sobre ela uma ordem regulada por leis. No discurso de Prout, a existência de Deus é uma conclusão necessária e naturalmente derivada do estudo sobre o comportamento químico dos corpos naturais.

Seguindo sua abordagem sobre a química, Prout trata dos corpos elementares e enaltece a noção de que, embora a quantidade de moléculas seja extraordinária, todas elas se formam a partir de poucos elementos. O texto traz uma tabela com 54 corpos simples, deixando de fora a luz e o calórico.

$\mathrm{O}$ primeiro grupo compreende os elementos que sustentam a combustão: oxigênio, cloro, bromo, iodo e flúor. Estes princípios são destacados pela sua notável tendência de se combinarem entre si e também com outros elementos. Ao detalhar algumas propriedades específicas, Prout faz considerações sobre a economia da Natureza e reconhece a ordem vigente das coisas como a realização dos desígnios do Criador. Por exemplo, depois de mencionar que o oxigênio tipicamente se combina mediante liberação de calor e luz no fenômeno da combustão, o autor afirma que, antes da existência dos animais, o mundo já havia sido criado com oxigênio em sua atmosfera. Deus teria adaptado suas criações posteriores com um aparelho respiratório adequado às propriedades e ao comportamento químico do gás já existente.

Prout toma como um fato que a condição atual do mundo seria a ideal e a mais perfeita, tal qual fora planejada pelo Criador. Assim, muitos argumentos parecem apenas observar sabedoria ao notar que as coisas são como são. O cloro, por exemplo, é apresentado como um elemento menos abundante e talvez menos importante que o oxigênio. No entanto, ele teria alguma relevância 
para os seres vivos, pois participava da composição do sal marinho. Se este princípio fosse encontrado isolado, como o oxigênio, na forma gasosa, ele seria um veneno, então Deus demonstra sua sabedoria e benevolência ao fazê-lo reativo, de modo que apareça prioritariamente na forma combinada, no sal, evitando seus efeitos nocivos em favor da vida (PROUT, 1834, p.98-99).

Seguindo a mesma lógica, Prout comemora que a distribuição e a abundância relativa dos elementos sejam perfeitas, sem excessos de algum princípio deletério ou a falta de outro essencial. Para a formação da água, de vital importância, é necessária maior medida em massa de oxigênio do que de hidrogênioe assim estes princípios foram distribuídos no mundo de maneira balanceada (PROUT, 1834, p.102).

O segundo grupo engloba os elementos combustíveis: hidrogênio, carbono, azoto, boro, silício, fósforo, enxofre e selênio. $\mathrm{O}$ autor traz rápidas descrições de cada elemento, abordando alguns deles em conjunto. Os comentários mais frequentes envolvem um registro das condições e dos locais em que cada elemento é naturalmente encontrado, e se participa de compostos necessários ou prejudiciais à vida.

Ao falar do carbono, Prout menciona a constante combinação deste princípio com o oxigênio, formando o deletério ácido carbônico. Logo em seguida ressalta que a Natureza, por meio de algum mecanismo compensatório, retira do ar esse ácido na mesma medida em que ele é produzido. Do azoto são ressaltadas algumas qualidades negativas. Não é reativo, nem combustível e nem sustenta a combustão. Não é ácido e nem alcalino. Não apresenta cheiro ou gosto. Todavia, Prout destaca que, quando esse princípio se combina em condições especiais, forma compostos vigorosos como a aquafortis, a amônia e o ácido prússico. $\mathrm{O}$ azoto garantiria neutralidade à atmosfera, de tal modo que esta não apresenta uma predominância ácida ou alcalina, nem de qualquer cheiro ou cor. 
Em seguida, apresenta-se o grupo dos metais imperfeitos ou metaloides, incluindo arsênio, antimônio e outros oito elementose uma sequência de parágrafos curtos trata das bases metálicas e dos vários metais que completam a tabela. Eventualmente, um elemento recebe maior atenção em função da presença dos seus compostos nos seres vivos. Este é o caso do cálcio que, pela formação da cal, teria óbvia importância na economia animal, sendo reconhecido como um dos poucos minerais que fazem parte de estruturas animais organizadas. Combinado ao fósforo e ao oxigênio, o cálcio constituiria a base dos ossos, enquanto que ligado ao carbono e ao oxigênio daria origem a conchas e cascos de diversas espécies.

Assim, as propriedades da cal fornecem outra admirável instância de adaptação para um propósito particular. Todos os compostos derivados da potassa e da soda são bastante solúveis em água, e são, portanto, limitados aos fluidos dos animais, onde sua presença é indispensável. Mas, para a existência de animais mais perfeitos, era necessário um esqueleto ou estrutura sólida, e tal não poderia ser formado a partir das solúveis soda ou potassa. Fazia-se necessária a introdução de outra substância mineral, imbuída das propriedades requeridas. A cal, tendo alguns de seus compostos sólidos e outros fluidos, é admiravelmente adaptada a este propósito, e assim foi escolhida (PROUT, 1834, p.112-113).

Nota-se que o autor não tem a intenção de explicar os processos de obtenção de cada elemento, tampouco as proporções ou condições específicas das suas combinações. Sua atenção é estritamente voltada à valorização das instâncias em que se pode perceber algum design, revelando nos compostos e processos químicos os meios pelos quais seriam concretizados os planos do Criador. 
Sobre a obtenção do ferro, tão fundamental na consolidação dos modos de vida praticados por sua sociedade, Prout se limita a afirmar que "só pode ser obtido puro mediante um processo elaborado" (1834, p.116). Em contrapartida, o autor se alonga ao reconhecer que o ferro tinha tantas utilidades que deveria ser considerado

não apenas como um artigo evidentemente planejado para o benefício do homem, mas como o instrumento pelo qual ele deveria conquistar e governar o mundo; assumindo assim o seu posto no lugar que the era evidentemente pretendido, o ápice da criação (PROUT, 1834, p.117).

As ênfases aplicadas por Prout sugerem que ele tomava a história do homem e seu domínio sobre os materiais como a realização dos desígnios de Deus. Então, se o homem fez suas ferramentas de ferro, é porque este elemento foi especificamente projetado para este fim. Isso gerava complicações para interpretar, por exemplo, o porquê da existência de elementos com propriedades venenosas, como são as do chumbo ou do arsênio. Reconhecendo essa dificuldade, Prout recorre a um argumento que fora utilizado por Paley (1802/2006), justificando a existência desses corpos deletérios como criações intermediárias ou subprodutos, reconhecidos por Deus como necessários ao alcance de um bem maior, que seria a formação dos compostos finais, úteis ou essenciais à vida (PROUT, 1834, p.168).

Passando da abordagem dos elementos para as leis que regem a sua combinação, Prout reconhece que a quantidade e a variedade de compostos era tão grande que, dada a aparente incompatibilidade dos corpos simples com a presente ordem do mundo, justificava-se pensar que seriam eles, os compostos, que o Criador teria em mente como os instrumentos da realização do 
seu projeto. Nessa perspectiva, as substâncias simples teriam sido criadas apenas como um meio para a realização final dos compostos, de modo que não fossem desrespeitadas as regras e limites originalmente impostos pelo próprio Criador sob a forma das leis naturais (PROUT, 1834, p.141).

As leis de combinação química descritas por Prout basicamente retomam as interações entre eixos polarizantes descritos inicialmente para explicar os estados de agregação. Prout apresenta uma leitura da teoria atômica de Dalton, mas recorre também às medidas volumétricas na interpretação das combinações químicas no estado gasoso. Como resultado, admite que a teoria corpuscular apresentada em seu texto não representava um consenso estabelecido entre os filósofos do período (PROUT, 1834, p.129). Entre suas peculiaridades, é interessante notar como a aceitação da hipótese de Avogadro conduz os argumentos de Prout à conclusão de que as moléculas de corpos simples, como os gases oxigênio, hidrogênio e cloro, deveriam ser duplas, sendo formadas por submoléculas. Para explicar as relações volumétricas entre produtos e reagentes em processos, Prout conclui, por exemplo, que as moléculas de água seriam formadas por estruturas contendo nove submoléculas, sendo três de oxigênio e seis de hidrogênio (PROUT, 1834, p.125-126).

A abordagem oferecida para os corpos compostos é rápida e essencialmente classificatória. Os compostos são divididos entre primários e secundários, de acordo com o caráter dos princípios envolvidos na sua formação. Os compostos secundários abrangeriam os sais, formados pela combinação de radicais advindos de um ácido e um álcalis. Já os primários incluiriam todos esses ácidos e álcalis, mais alguns compostos neutros como água, álcool, éter, óleos fixos e voláteis, e betume.

De modo geral, nota-se que a apresentação da química promovida por Prout tem foco na simples caracterização dos princípios elementares e das classes de compostos. Quando se 
propõe a descrever transformações, como a precipitação dada pela mistura de nitrato de prata e sal marinho, o autor o faz apenas para ressaltar o quão diminutas são as partículas últimas que compõem os corpos da matéria (PROUT, 1834, p.171).

O mesmo se percebe em relação aos mecanismos de síntese e decomposição, que eram tratados por outros autores da época como vias essenciais à produção do conhecimento químico, mas que não têm o mesmo destaque na abordagem de Prout (BALDINATO, 2016). Entendemos que isso apenas reflete que esse autor não tinha a intenção de explicar como os químicos produziam suas verdades sobre o mundo. Seu propósito era apenas apresentar essas verdades como instâncias reveladoras dos atributos do Criador.

$\mathrm{Na}$ recapitulação que fecha o primeiro tomo do livro, Prout resume o que seriam os pilares da teoria atômica da matéria para, em seguida, apresentar sua leitura teológica. Os pilares elencados são: 1) todos os corpos gasosos se combinam em referência a múltiplos inteiros do seu volume; 2) volumes iguais de diferentes gases apresentam diferentes massas e, adotando-se a hipótese do número de moléculas ser o mesmo nesses gases, deriva-se a conclusão de que as moléculas de cada gás devem ter um peso característico; 3) todos os corpos devem se combinar com referência ao seu peso; e 4) os números que representam a relação entre as gravidades específicas dos gases são chamados de pesos atômicos, ou pesos moleculares (PROUT, 1834, p.148-149).

Como mencionamos, Prout via no mundo natural e no progresso da condição humana a realização do que fora planejado por Deus no momento da Criação. Logo, se os compostos são mais abundantes que os corpos elementares, é porque Deus assim o queria. No início, Deus aplicou ordem ao caos, definindo toda a matéria. Em seguida, Prout sugere que o "Fiat lux" pode ser lido como a entrada das formas imponderáveis na criação (PROUT, 1834, p.150). Assim, o autor interpreta quais seriam os 
fins almejados pelo Criador, e reconstrói umaespécie de sequência lógica que os tornaria possíveis dentro dos limites que Ele próprio estabeleceu.

De acordo com os argumentos de Prout, qualquer modificação na qualidade dos compostos que permeiam a Natureza produziria consequências catastróficas. Se a base do ácido que compõe o sal marinho não se combinasse firmemente ao radical alcalino e preservasse suas qualidades corrosivas, atacaria o leito de rocha e toda a matéria calcária, destruindo imensas porções de solo e liberando tanto ácido carbônico no ar que extinguiria a vida animal. E se água tivesse cheiro ou gosto? Se o ar fosse opaco? $\mathrm{E}$ se fossem invertidas as proporções de terra e água no globo? Ou de ferro e ouro? Diamante e carvão? Prout conclui que qualquer mudança seria desastrosa e, por esta lógica, que tudo o que se criou depois foi perfeitamente adaptado ao que existia antes (PROUT, 1834, p.151-158).

A água e o ar, por exemplo, foram definidos antes das plantas e dos animais. Esses últimos dependem dos primeiros para existir, e não o contrário. Questiona-se, portanto, por que seriam os primeiros tão ajustados à existência destes últimos. Para o autor, parece óbvio que é porque foram planejados para sustentar o que seria criado em seguida. Prout acrescenta que há algo de mais complexo nos corpos vivos, que exclui a possibilidade de que estes tenham derivado sua existência espontaneamente a partir de formas de organização inferiores, pois

não há relação necessária de causa e efeito entre a existência anterior de água e ar e a existência subsequente de plantas e animais; como alguns parecem ter imaginado. Disso também decorre, irresistivelmente, que plantas e animais foram criados, tendo suas propriedades adaptadas às da água e do ar em algum período ulterior, e por algum agente externo e superior (PROUT, 1834, p.159-160). 
Prout reconhece que a vida é dependente da condição fluida da água, que só existe numa faixa estreita de temperaturas. Sendo assim, é providencial que o globo terrestre tenha sido posicionado justamente a uma distância do Sol que, obedecendo às leis primeiras de propagação da luz e do calor, faz com que esses princípios nos atinjam com a intensidade apropriada. $\mathrm{O}$ autor não admite que o acaso poderia levar a uma combinação tão feliz de fatores necessários ao estabelecimento da vida, e enaltece o ajuste das quantidades e das qualidades de todos os recursos dirigidos a sua realização.

A parte química do tratado se encerra com as respostas formuladas pelo autor para defender seu argumento do design contra duas classes conhecidas de opositores. A primeira seria daqueles que negavam a existência de uma Causa Primeira, admitindo a ordem do mundo como decorrente de um conjunto de leis naturais que não teriam sido criadas num dado momento, existindo eternamente. A estes Prout chama de verdadeiros ateístas ou panteístas, pois tratariam das leis naturais como se estas fossem os próprios deuses. Já a segunda classe de opositores admitiria a existência de um Deus criador, mas negaria que a sua sabedoria ou demais atributos pudessem ser acessados pelo intelecto humano (PROUT, 1834, p.173).

Prout concede a este segundo argumento que as instâncias que ele trata como de design limitavam-se, de fato, a "provável design", numa relação que não poderia ser comprovada. No entanto, contrapõe que seus opositores também seriam incapazes de provar a falsidade do argumento, o que, para ele, anulava a crítica (PROUT, 1834, p.176).

Uma ideia mais interessante aparece na resposta ao primeiro tipo de oposição. $\mathrm{O}$ autor interpõe que Deus opera por meio das leis naturais, mas que elas não existiriam sem a Sua vontade. Prout trata dos recentes achados fósseis da geologia como evidências para afirmar que as próprias leis da Natureza 
não seriam eternas, minando um aspecto central da tese de seus opositores. Ele reconhece uma tendência da Natureza pela manutenção de equilíbrios que decorreriam da distribuição planejada das quantidades e qualidades dos corpos que interagem, tendo reflexos sobre toda a matéria. A cada momento, corpos abaixo da condição de equilíbrio vigente tenderiam a se combinar sinteticamente, enquanto aqueles que por algum agente foram forçados em combinações mais complexas, quando deixados à mercê da sua própria ação, tenderiam naturalmente à decomposição (PROUT, 1834, p.163). Essa linha de raciocínio antecipa uma noção que será aprofundada na última parte do tratado, sobre a digestão, sugerindo a necessidade de um "agente orgânico" para que as substâncias simples minerais pudessem se combinar em corpos vivos, mais complexos, e que, após o fim da vida, entrariam espontaneamente em decomposição (PROUT, 1834, p.429). Mas aqui essa ideia é colocada para ressaltar a existência de evidências de que as condições gerais do clima no globo não foram constantes ao longo de toda a história. Assim, diferentes condições de equilíbrio teriam sido povoadas por diferentes espécies vegetais e animais, todas elas criadas em momentos específicos. No discurso de Prout não se admite que novas espécies possam surgir no mundo por qualquer mecanismo que não seja a Criação, e isso se opõe radicalmente à suposição de que a vida poderia decorrer da ação conjunta das leis naturais.

As espécies atuais de seres organizados, em todos os casos, são produzidas apenas pelo processo de criação; e se elas fossem exterminadas, não há processos naturais ocorrendo no mundo que possam nos levar a crer que, por qualquer lei da natureza, tais seres organizados poderiam ser reproduzidos. Quer dizer, não podemos conceber que hidrogênio, carbono, oxigênio e azoto, junto à luz e ao calor, etc., pelo que conhecemos das suas propriedades, 
seriam um dia capazes, por si mesmos, de se combinarem de modo a formar uma planta ou animal(PROUT, 1834, p.163-164).

O segundo tomo do tratado anuncia que o trabalho dos meteorologistas começa onde termina o dos geólogos, isto é, estudando o equilíbrio atual do globo e as forças que nele operam sobre os efeitos do clima. Prout retoma o argumento de que uma rápida análise da composição de diferentes extratos de solo permitiria concluir que o mundo passou por períodos menos tranquilos, intercalando convulsões e calmaria. Daí se deduz que, se o mundo não é assim desde sempre, é porque teve um começo e, a partir de então, vem se transformando sob a ordem das leis naturais, até acomodar os fins para os quais foi criado (PROUT, 1834, p.178-180).

$\mathrm{Na}$ leitura de Prout, esses fins envolveriam a ocupação da Terra pelo homem e outras espécies vivas. Assim, o planeta teria sido preparado para abrigar a vida mediante ciclos de convulsão e estabilidade que, com o passar das eras, promoveram a mistura adequada dos princípios elementares, dividindo a superfície do globo em proporções ideais de terra e água, garantindo também o seu recobrimento uniforme pelos gases atmosféricos.

Prout enaltece o fenômeno da difusão como o responsável pelo equilíbrio de composição da atmosfera ao redor do globo, e especula que a proporção constante de quatro partes de gás nitrogênio para uma de oxigênio remete, provavelmente, a uma antiga combinação química, pois não poderia ser acidental. Logo em seguida, no entanto, o autor reconhece que os componentes do ar atmosférico não se encontram combinados quimicamente num composto (ao contrário do que havia afirmado em seu artigo de 1815), mas mantêm essa proporção fixa mesmo estando livres, o que representa uma divina exceção às leis gerais da Natureza (PROUT, 1834, p.190-194).

Embora não seja ilustrada, essa parte do texto descreve em detalhes as zonas climáticas e apresenta medidas médias de 
temperatura atribuídas a linhas isotérmicas do globo. Prout trata dos constituintes primários do clima como aqueles que decorrem da distribuição de luz e calor em função da dinâmica de posicionamento do sistema Terra/Sol e do formato globular do planeta. Já os constituintes secundários remetem a aspectos internos da Terra, como a distribuição de terra e água na superfície e as propriedades da atmosfera.

Por organização didática, Prout divide sua argumentação sobre alguns problemas de estudo em partes isoladas, integrando-as ao final. Por exemplo, para tratar da atmosfera como uma mistura de gases e vapor, ele primeiro detalha qual seria o comportamento de uma atmosfera de ar seco, depois uma de puro vapor d'água. No final, trata da atmosfera existente no planeta como um misto desses dois extremos (PROUT, 1834, p.282).

Em relação à maior parte dos saberes ligados a fenômenos meteorológicos, o texto apenas lista os resultados da investigação filosófica e não se propõe a explicar como se chegou a eles. Assim, coloca-se como fato que mais de 50\% dos raios de luz são bloqueados pela atmosfera, ou que a taxa de evaporação da água aumenta com a temperatura, sem maiores explicações (PROUT, 1834, p.227-278).

Poucas ideias são abordadas em maior detalhe, revelando argumentos interessantes, mas que nem sempre refletem visões consensuais dos filósofos do período. Sobre o campo magnético da Terra que orienta as bússolas, por exemplo, afirma-se que ele seria derivado do calor do Sol que incide sobre a Terra em rotação. Prout identifica um permanente desequilíbrio de calor entre as áreas iluminadas e escuras do globo, movendo-se continuamente de leste para oeste. Pelo que o autor chama de "princípios termoelétricos", surgiria uma corrente elétrica em movimento circular no interior da Terra, próximo à superfície, induzindo um campo magnético entre os seus polos (PROUT, 1834, p.233). 
Percebe-se nessa explicação o recurso à decomposição do calor em eletricidade e essa mesma ideia é ainda empregada no texto para interpretar outros fenômenos meteorológicos. As tempestades de raios são apresentadas como manifestações elétricas na atmosfera, que dependeriam da presença de água num estado condensado, uma vez que vapor e ar seco são reconhecidos como maus condutores. Prout chama a atenção para o curioso fato de que as tempestades de raios são usualmente seguidas por bruscas quedas de temperatura e pela sensação de frio. Assim, o autor sugere que tomar a eletricidade como produto da decomposição do calor daria uma explicação possível para o fenômeno, ainda que esta não despertasse consenso entre os filósofos (PROUT, 1834, p.338).

Em todos os casos, os fenômenos naturais são apresentados como instâncias de design dignas de admiração. Assim, por exemplo, a existência da propriedade conhecida como calor latente de fusão ou de ebulição seria responsável pela prevenção de inundações e outras catástrofes climáticas, pois impediria que o gelo e o vapor se formassem instantaneamente, mantendo processos lentos e graduais que preservariam o equilíbrio da natureza. $\mathrm{Da}$ mesma forma, considerando as instâncias naturais de condensação, Prout afirma que devíamos muito à neve, por sua brancura, leveza e baixa condutividade térmica. Respectivamente, essas três propriedades trariam os benefícios de: refletir a luz e o calor, mantendo a condição permanente do gelo nas regiões em que ele é essencial; cair suavemente e sem danificar a vegetação, em comparação com massas sólidas de gelo que seriam deletérias e proteger a vegetação recoberta do frio intenso da atmosfera (PROUT, 1834, p.229-327).

Mesmo os fenômenos que admitiam explicações relativamente simples - como as correntes oceânicas, que podiam ser plenamente interpretadas pelos princípios da hidrostática e da pneumática - são apontados como dignos de nota. $\mathrm{O}$ argumento 
de design nestes casos se colocaria, portanto, não nos princípios geradores, mas na sua aplicação exata sobre os locais e contextos em que eram necessários para garantir o equilíbrio da Natureza (PROUT, 1834, p.358).

No entanto, os principais exemplos de design apresentados nesta parte do tratado remetem às situações em que as leis naturais seriam providencialmente violadas em favor da vida. $\mathrm{O}$ comportamento anômalo da água que provoca sua expansão na formação do gelo é tratado por Prout como "a mais extraordinária instância de design em toda a Natureza” (PROUT, 1834, p.250). A segunda anomalia a ser destacada é a que faz com que os componentes do ar, mesmo estando apenas misturados e não combinados num composto químico, apresentem-se distribuídos uniformemente, numa proporção fixa, ao redor de todo o globo.

[...] somos inevitavelmente levados à conclusão de que o Criador da água e do ar ocasionou essas anomalias, propositadamente, para prevenir dificuldades que teriam feito da existência orgânica uma impossibilidade física (PROUT, 1834, p.250).

Assim, para que a água não se congele; e que o ar não se torne irrespirável; leis precisam ser infringidas - e ELAS SÃO INFRINGIDAS; precisamente onde a sua violação, tanto em grau quanto em natureza, é indispensavelmente necessária à existência orgânica (PROUT, 1834, p.360, grifos no original)

Como faz questão de enfatizar o autor, é emblemático que essas exceções às leis naturais se apliquem justamente à água e ao ar, tão essenciais e intimamente ligados à vida na Terra.

Os últimos tópicos da parte meteorológica do tratado dirigem a atenção do leitor para as adaptações observáveis nas plantas e animais que os tornam aptos a existirem nas diferentes zonas 
climáticas do globo. Depois de enaltecer como cada animal e planta se mostram perfeitamente adaptados às condições físicas e climáticas do ambiente em que vivem, Prout traz à tona $o$ argumento da interdependência entre os reinos, afirmando que os vegetais cumpririam a função de conectar os animais aos minerais nutritivos da terra, garantindo seus meios de subsistência. Para Prout, toda a exuberância e os detalhes das plantas não fariam sentido como fins em si mesmos. Por que envolver a semente no fruto? Por que o colorido das flores? As variedades de folhas e raízes? Em si, as plantas não revelariam sinais de design, mas é na sua interação com os animais que este argumento se colocaria (PROUT, 1834, p.377).

Percebe-se um discurso de valorização das utilidades na narrativa de Prout, que é coerente com a perspectiva teleológica da teologia natural. A providência é inferida à medida que se racionalizam os fins para os quais cada detalhe do mundo natural contribui. Para o autor, nada teria sentido se não fosse preparado para favorecer o domínio do homem sobre o globo. Era necessário e lógico colocar no globo um ser capaz de admirar e tirar proveito de toda a exuberância e diversidade da Criação. A menção sagrada à "imagem e semelhança" do Criador deveria referir-se, portanto, à posse da razão e à capacidade de refletir (PROUT, 1834, p.403).

Prout trata do domínio do homem sobre a criação como a realização do projeto divino. $O$ homem não é mais forte nem melhor adaptado em termos físicos, mas é dotado da razão, que the permite superar dificuldades de toda sorte e o torna capaz, inclusive, de vislumbrar a ordem e os fins traçados pelo Criador. $\mathrm{O}$ autor não encontra na teologia natural uma resposta categórica para a dúvida eterna sobre o que seria do homem após a morte, mas sugere não haver lógica no fim completo daquele que enxerga o plano de Deus (PROUT, 1834, p.404-412).

O terceiro e último tomo do tratado é dedicado à química da organização, isto é, à formação dos componentes de corpos vivos 
a partir dos nutrientes elementares disponíveis na matéria inanimada. Como já antecipamos, Prout admite a existência de agentes orgânicos como uma dedução lógica e natural, dada a impossibilidade de que princípios inorgânicos como calor, luz e eletricidade se juntem espontaneamente à matéria ponderável dando origem a corpos organizados como plantas e animais, por mais simples que estes sejam. $\mathrm{O}$ autor recorre à autoridade de Paley e sugere a existência não apenas de um, mas vários agentes orgânicos, com diferentes níveis de complexidade. Estes responderiam pela diversidade de seres vivos que ocupa o planeta.

A natureza íntima do agente ou dos agentes orgânicos, ou seja qual for o nome que escolhamos para designar as energias peculiares que existem nas plantas e animais, e pelas quais eles se distinguem da matéria inanimada, é e provavelmente sempre será inteiramente desconhecida para nós(PROUT, 1834, p.429).

Embora não tenha a pretensão de precisar o que seriam esses agentes orgânicos, o autor não hesita na descrição das suas capacidades. Basicamente, esses agentes promoveriam combinações peculiares dos elementos químicos, produzindo arranjos moleculares e corpos que o químico mais bem treinado seria incapaz de imitar. Prout argumenta que os agentes orgânicos poderiam atuar individualmente sobre cada molécula e assim, "de acordo com o propósito planejado, rejeitar algumas moléculas e colocar outras em contato" (PROUT, 1834, p.436). Essas operações não violariam nenhuma das leis naturais de afinidade química ou de coesão, mas apenas se processariam numa escala que permitiria alcançar produtos diferentes dos obtidos nos frascos de reação convencionais.

A abordagem desta parte se inicia com uma longa citação de Berzeliusque comparava o corpo de um ser vivo com um 
laboratório no qual várias operações químicas ocorreriam continuamente (PROUT, 1834, p.414) ${ }^{63}$.

Prout atribui aos agentes orgânicos a capacidade de combinar substâncias por vias sintéticas, tendo como resultado os corpos organizados. Esses produtos estariam, de algum modo, num patamar acima da condição de equilíbrio regida pelas leis naturais e, portanto, entrariam em processo de decomposição espontaneamente, a partir do momento em que se encerrasse a vida daquele corpo. Assim, a própria ação dos agentes orgânicos era dependente da existência da vida como um princípio abstrato e anterior à ocorrência de qualquer das suas funções.

Para Prout, era a vida que provocava a organização da matéria e não o contrário. $\mathrm{O}$ autor não admitia que qualquer corpo pudesse gerar outro mais complexo do que si mesmo. Haveria, então, uma hierarquia de agentes orgânicos. Os mais simples combinariam as substâncias inorgânicas gerando compostos orgânicos simples, como açúcares. Em seguida, outros agentes mais complexos assimilariam estes produtos formando estruturas maiores, como o amido ou a lignina, que dá a estrutura das plantas. Assim, Deus teria criado tantos agentes orgânicos quantos fossem necessários para a constituição dos corpos animais mais complexos.

Da mesma forma, um cão não poderia ser gradualmente convertido num macaco, e este não podia dar origem ao homem. Cada ser mais complexo requereria um ato de criação, e seria dotado da capacidade de se multiplicar, mas apenas da forma como foi concebido (PROUT, 1834, p.438-440).

As formas mais simples de organização se dariam pela atividade das plantas que, enquanto expostas à luz, seriam capazes de "digerir o ácido carbônico", assimilando o seu componente de carbono e devolvendo o oxigênio à atmosfera (PROUT, 1834, p.449). A sequência da narrativa considera as formas de nutrição

63 O original da citação de Prout se encontra em Berzelius (1831, p.1). 
de plantas e animais, descreve os órgãos do aparelho digestivoe caracteriza três classes essenciais de nutrientes: a sacarínea, a oleaginosa e a albuminosa. Nesse trecho, Prout descreve a composição de alguns representantes dessas classes de modo semelhante ao que apresentara numa comunicação à Royal Society, que lhe rendeu uma medalha (PROUT, 1827). Por design, todas essas classes de nutrientes estariam presentes no leite, sendo esta a única substância especificamente planejada como um alimento em seu estado brutoe que serviria de modelo para toda a nutrição (PROUT, 1834, p.478).

Dos animais, Prout descreve as ações do estômago e do duodeno e afirma que, comparadas a esses dois órgãos, as partes seguintes do aparelho alimentar seriam insignificantes. Conclui-se, pela análise da digestão, que os organismos animais são mais bem adaptados para a ingestão de substâncias não puras (em oposição aos cristais), e que as formas puras de açúcar, álcool e óleos são muito mais difíceis de serem processadas. Prout lamenta que o homem, por vezes, se afastaria da razão e buscaria agradar ao paladar de modo irrefletido, sobrecarregando seu organismo e debilitando-o. A cristalização de materiais nos fluidos corporais (cujo estudo consolidou a carreira de Prout como médico) seria, portanto, derivada de maus hábitos alimentares (PROUT, 1834, p.508).

Em termos de teologia natural, encontram-se dois argumentos principais nesta parte do tratado. O primeiro é o que atribui à vida um conjunto de agentes capazes de construir e manter estruturas organizadas que ultrapassam as leis naturais da matéria inorgânica. E o segundo remete a um detalhe da relação de dependência entre os reinos, tomando como providencial que praticamente todos os alimentos partilhem de uma composição semelhante em termos dos seus elementos constituintes. Assim, não é necessário que os animais mais organizados arranjem, mas apenas rearranjem esses princípios, daí tirando a sua nutrição. A 
tarefa de dar uma organização básica a esses nutrientes caberia aos seres inferiores, do reino vegetal, que iniciam a cadeia alimen$\operatorname{tar}$ (PROUT, 1834, p.511).

$\mathrm{Na}$ conclusão do volume, Prout traz sua leitura dos rumos que deveriam pautar o avanço da química. Dado que esta era retratada como uma ciência experimental, fundada na observação, seria impossível antecipar os conhecimentos e fatos que ela deveria trazer à tona no futuro. $\mathrm{O}$ caminho mais promissor, no entanto, seria o de dirigir experimentos e observações de modo a explorar as leis de quantidade no mundo natural. Para continuar contribuindo com o campo da fisiologia, Prout afirma que a química deveria "confinar-se rigidamente à aferição do que o princípio vivo faz; e de como ele opera sobre princípios inorgânicos"(PROUT, 1834, p.548-549).

\section{Considerações finais}

Nota-se alguma contradição no discurso de Prout quando ele afirma que a abordagem útil da química é meramente descritiva, e que se perderia em vazio quando tenta ser explicativa sobre os fenômenos (PROUT, 1834, p.549). Essa visão nos parece conflitante com as muitas páginas de seu tratado que se prestam, justamente, a explicar os mecanismos da interação de partículas por meio de eixos polarizantes e arranjos moleculares.

Outro ponto de contradição se refere à afirmação inicial de que a obra de Deus se mostra tanto mais maravilhosa e digna de admiração quanto mais ocultos forem os seus meios de realização. Prout chega a afirmar que Deus trilhava caminhos óbvios quando operava por vias mecânicas, como no movimento dos corpos celestes ou na própria configuração do esqueleto e da estrutura muscular dos animais (PROUT, 1834, p.11). Já quando a Sua graça se conduzia por vias químicas, pelo seu aspecto obscuro, seus efeitos pareceriam mais dignos de admiração. A contradição 
se dá, novamente, quando o filósofo se propõe a esclarecer essas vias químicas, retirando delas o seu mistério e tornando seus efeitos previsíveis mediante o conhecimento de princípios simples como a atração e a repulsão elétrica (TOPHAM, 1993, p.241).

Todavia, seria o avanço da filosofia natural uma justificativa para libertar o homem do seu apreço pela sabedoria e pelo poder de um Criador? Nas palavras de Prout, não.

O pouco que podemos saber sobre Ele, nós o sabemos quase inteiramente a partir das Suas obras. Consequentemente, aquele que mais estudou as Suas obras será o mais qualificado [...] a formar uma noção adequada sobre Ele. Assim, medir, pesar, estimar, deduzir, podem ser considerados como os mais nobres privilégios desfrutados pelo homem; pois é somente por meio destas operações que ele se torna apto a seguir as pegadas do seu Criador e a descobrir Seus magníficos intentos. Orientado por estes, ele vê e aprecia a sabedoria e o poder, a justiça e a benevolência que reinam sobre toda a criação: ele não olha mais fixamente para o céu com estúpido espanto; nem teme o trovão como algo que manifesta a fúria de um Deus vingativo(PROUT, 1834, p.356).

Dado o caráter geral do público ao qual se dirigiam os Bridgewater Treatises, entendemos essa coleção como uma iniciativa de divulgação dos vários ramos da filosofia natural. Notamos, no entanto, que o conteúdo de química abordado por Prout traz algumas diferenças em relação ao que encontramos nos textos de outros divulgadores do período, tais como Samuel Parkes e de Jane Marcet (BALDINATO; PORTO, 2009, 2015). Sendo Prout um praticante da química, ele trata de temas não consensuais com maior liberdade, apresentando predileções teóricas e interpretações que refletem seu ponto de vista pessoal sobre 
alguns temas. Isso torna o texto mais difícil, pois o afasta do que seria uma simples introdução à química. Reforçamos, portanto, que nosso interesse pelo detalhamento desta obra se dá em função do argumento da teologia natural, que nos permite aprofundar como a investigação química admitia um convívio harmônico com convicções religiosas em textos que apresentavam essa ciência ao público não especializado.

\section{Referências}

AINSWORTH, T. Form vs. Matter. In: ZALTA, E. N. (Ed.) The Stanford Encyclopedia of Philosophy, Spring 2016 Edition.

Disponível em: <https://plato.stanford.edu/archives/spr2016/ entries/form-matter/>. Acesso em 10 mai 2019.

ANÔNIMO. Obituary. Earl of Bridgewater. The Gentleman's Magazine and Historical Chronicle, v. XCIX, n.22th new series, p.58-560, 1829.

ANÔNIMO. Chemistry, Meteorology and the Function of Digestion considered with Reference to Natural Theology, by William Prout (review). The Medico-Chirurgical Review, v.24, p.385-400, 1836.

ANÔNIMO. Memoir of Dr. Prout, F.R.S. The Medical Times: A Journal of Medical Science, Literature, Criticism, and News, v.1, p.15-17, 1850.

BAHAR, S. Jane Marcet and the limits to public science. The British Journal for the History of Science, v.34, n.01, p.29-49, 2001. 
BALDINATO, J. O. Conhecendo a Química: Um estudo sobre obras de divulgação do início do século XIX. 169p. Tese (Doutorado em Ensino de Ciências), Universidade de São Paulo, 2016.

BALDINATO, J. O.; PORTO, P. A. Jane Marcet E Conversations on Chemistry: Divulgando a Química no início do Século XIX. Anais do VII Encontro Nacional de Pesquisa em Educação em Ciências. Anais... Florianópolis, SC, Brasil: 2009

BALDINATO, J. O.; PORTO, P. A. Popularizing chemistry in early nineteenth-century: Samuel Parkes and his Chemical Catechism. In: ALFONSO-GOLDFARB, A. M. et al., (Eds.). Crossing Oceans: Exchange of Products, Instruments and Procedures in the History of Chemistry and Related Science (Coleção CLE). 1. ed. Campinas: UNICAMP - CLE, 2015, p.43-63.

BerZeliUs, J. J. Traité de Chimie. 2e Partie - Chimie Organique. Tome 5e. Tradução M. Esslinger. Paris: Firmin Didot Frères, J. B. Baillière, 1831.

BIRD, G. Observations on Urinary Concretions and Deposits: with an account of the Calculi in the Museum of Guy's Hospital. In: BARLOW, G. H.; BABINGTON, J. P. (Eds.). Guy's Hospital Reports. London: Samuel Highley, 1842.v. VII. p.175-232.

BROCK, W. H. The life and work of William Prout. Medical History, v.9, n.2, p.101-126, 1965.

BROCK, W. H. The selection of the authors of the Bridgewater Treatises. Notes and Records of the Royal Society of London, v.21, n.2, p.162-179, 1966. 
BROOKE, J. H. Natural Theology in Britain from Boyle to Paley. In: BROOKE, J. H.; HOOYKAAS, R.; LAWLESS, C. (Eds.). New Interactions between theology and Natural Science. Milton Keynes: Open University Press, 1974, p.8-54.

COLEY, N. G. Alexander Marcet (1770-1822), physician and animal chemist. Medical history, v.12, n.4, p.394-402, 1968.

DREIFUSS, J. J.; SIGRIST, N. T. The making of a bestseller: Alexander and Jane Marcet's Conversations on Chemistry. In: LYKKNES, A.; OPITZ, D. L.; TIGGELEN, B. VAN (Eds.). For Better or For Worse? Collaborative Couples in the Sciences. Basel: Springer, 2012. p.19-32.

GILBERT, D. Statement respecting the Legacy left by the late Earl of Bridgewater, for rewarding the Authors of Works, to be published in pursuance of his Will; and demonstrative of the Divine Attributes, as manifested in the Creation. The Philosophical Magazine, v. IX, n.1, p.200-202, 1831.

GLASSTONE, S. William Prout (1785-1850). Journal of Chemical Education, v.24, n.10, p.478-481, 1947.

GORDIN, M. D. The Textbook Case of a Priority Dispute:

D. I. Mendeleev, Lothar Meyer, and the Periodic System. In: BIAGIOLI, M.; RISKIN, J. (Eds.). Nature Engaged: Science in Practice from the Ranaissance to the Present. New York: Palgrave Macmillan, 2012, p.59-82.

LEAL, K. P.; FORATO, T. C. M.; BARCELLOS, M. E. Ciência e religião em conflito na sala de aula: episódios históricos como propostas para a formação de professores. Revista Brasileira de História da Ciência, v.9, n.2, p.235-251, 2016. 


\section{LIGHTMAN, B. V. Victorian Popularizers of Science:}

Designing Nature for New Audiences. Chicago and London: The

University of Chicago Press, 2007.

LINDEE, M. S. The American Career of Jane Marcet's

Conversations on Chemistry, 1806-1853. Isis, v.82, n.1, p.9-23, 1991.

MARCET, J. H. Conversations on Chemistry. 12. ed., v.2. London: Longman, Rees, Orme, Brown, Green, \& Longman, 1832.

MENDELEEV, D. I. Principles of Chemistry. v.2. Tradução G. Kamensky. 5. ed. London: Longmans, Green, and Co., 1891.

OLIVEIRA, R. A.; SILVA, A. P. B. A história da Ciência no ensino: diferentes enfoques e suas implicações na compreensão da ciência. Anais do VIII Encontro Nacional de Pesquisa em Educação em Ciências. Anais... Campinas, 2011.

PALEY, W. Natural theology. New York: Oxford University Press, 2006.

PARKES, S. The chemical Catechism. 12. ed. London: Baldwin, Cradock, and Joy, 1826.

PORTO, P. A. História e filosofia da ciência no ensino de química: Em busca dos objetivos educacionais da atualidade. In: SANTOS, W. L. P.; MALDANER, O. A. (Eds.). Ensino de química em foco. Ijuí: Unijuí, 2010, p.159-180.

PROUT, W. On the Relation between the Specific Gravities of Bodies in their Gaseous State and the Weights of their Atoms. Annals of Philosophy, v. VI, p.321-331, 1815. 
PROUT, W. Correction of a Mistake in the Essay on the Relation between the Specific Gravities of Bodies in their Gaseous State and the Weights of their Atoms. Annals of Philosophy, v. VII, p.111-113, 1816.

PROUT, W. On the ultimate composition of simple alimentary substances; with some preliminary remarks on the analysis of organized bodies in general. Philosophical Transactions of the Royal Society of London, n.2, p.355-388, 1827.

PROUT, W. Chemistry, Meteorology and the function of Digestion considered with reference to Natural Theology. 1. ed. London: William Pickering, 1834.

ROBSON, J. M. The Fiat and Finger of God: The Bridgewater Treatises. In: HELMSTADTER, R. J.; LIGHTMAN, B. V (Eds.).

Victorian Faith in Crisis. Stanford: Stanford University Press, 1990. p.71-125.

ROSENFELD, L. The chemical work of Alexander and Jane Marcet. Clinical Chemistry, v.47, n.4, p.784-792, 2001.

SEQUEIRA, M.; LEITE, L. A historia da ciência no ensino -aprendizagem das ciências. Revista Portuguesa de Educação, v.1, n.2, p.29-40, 1988.

THOMSON, T. Some Observations on the Relation between the Specific Gravities of Bodies in their Gaseous State and the Weights of their Atoms. Annals of Philosophy, v. VII, p.343-346, 1816.

TOPHAM, J. R. Science and popular education in the 1830s: the role of the Bridgewater Treatises. The British Journal for the History of Science, v.25, n.4, p.397-443, 1992. 
TOPHAM, J. R. "An infinite variety of arguments": The Bridgewater Treatises and British Natural Theology in the 1830s. Lancaster: University of Lancaster, 1993.

TOPHAM, J. R. Beyond the "Common Context". Isis, v.89, n.2, p.233-262, 1998.

TOPHAM, J. R. Science, Natural Theology, and the Practice of Christian Piety in Early-Nineteenth-Century Religious Magazines. In: CANTOR, G.; SHUTTLEWORTH, S. (Eds.). Science Serialized: Representantion of the Sciences in Nineteenth-Century Periodicals. Cambridge: The MIT Press, 2004, p.37-66. 